\title{
POTENTIOMETRIC DETERMINATION OF SULFATE WITH EDTA AND THE CUPRIC-SELECTIVE ELECTRODE
}

E. W. Baumann

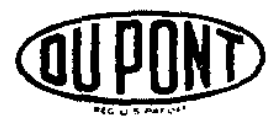

SAVANNAH RIVER LABORATORY AIKEN, SOUTH CAROLINA 29801 


\section{NOTICE}

This report was prepared as an account of work sponsored by the United States Government. Neither the United States nor the United States Energy Research and Development Administration, nor any of their contractors, subcontractors, or their employees, makes any warranty, express or implied, or assumes any legal liability or responsibility for the accuracy, completeness or usefulness of any information, apparatus, product or process disclosed, or represents that its use would not infringe privately owned rights.

Printed in the United States of America

Available from

National Technical Information Service

U.S. Department of Commerce

5285 Port Royal Road

Springfield, Virginia 22161

Price: Printed Copy $\$ 3.50 ;$ Microfiche $\$ \mathbf{3 . 0 0}$ 
DP- 1442

Distribution Category: UC -4

\section{POTENTIOMETRIC DETERMINATION OF SULFATE WITH EDTA AND THE CUPRIC-SELECTIVE ELECTRODE}

by

Elizabeth W. Baumann

Approved by

R. L. Folger, Research Manager

Analytical Chemistry Division

Publication Date: November 1976

E. I. DU PONT DE NEMOURS AND COMPANY SAVANNAH RIVER LABORATORY

AIKEN, SOUTH CAROLINA 29801

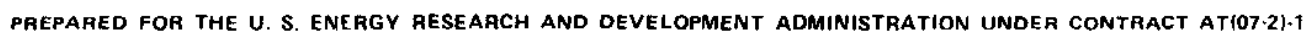


Sulfate was indirectly determined by precipitating sulfate as $\mathrm{BaSO}_{4}$ and then dissolving $\mathrm{BaSO}_{4}$ in excess ammoniacal EDTA. The excess EDTA was titrated potentiometrically with $\mathrm{La}^{3+}$. A cupric-selective electrode was used to detect the end point. About $10^{-3} \mathrm{M} \mathrm{SO}_{4}{ }^{2-}$ was determined in $3 \mathrm{M} \mathrm{HCl}$ solutions of metal oxides with a relative standard deviation of $3.5 \%$ and a bias of $+4 \%$. 


\section{CONTENTS}

$\begin{array}{lll}\text { Introduction } & 5 \\ \text { Experimental } & \text { Method } & 5 \\ \text { Principle } & 5 & \\ \text { Reagents } & 6 & \\ \text { Apparatus } & 6 & \\ \text { Procedure } & 6 & \\ \text { Titration Curves } & 7 & \\ \text { Evaluation of } & \text { Method } & 9 \\ \text { Application } & 9 & \\ \text { Conclusions } & 11 \\ \text { References } & 12\end{array}$




\section{POTENTIOMETRIC DETERMINATION OF SULFATE WITH} EDTA AND THE CUPRIC-SELECTIVE ELECTRODE

\section{INTRODUCTION}

A number of methods have been proposed for indirect complexometric determination of sulfate. ${ }^{1}$ The basic procedure consists of precipitating barium sulfate and determining the barium associated with the precipitation by complexometric titration. An inherent error in this procedure lies in the nature of the barium sulfate precipitate, which is not strictly stoichiometric and which may occlude other ions. ${ }^{2}$ Another difficulty has been the choice of a suitable visual indicator for the titration.

At the Savannah River Laboratory, a procedure is used in which precipitated barium sulfate is dissolved in excess ammoniacal ethylenediaminetetraacetic acid (EDTA); the excess EDTA is determined by titrating with $\mathrm{La}^{{ }^{+}}$with arsenazo metal indicator. The presence of barium mutes the color change of the indicator and causes a fading end point, which is difficult to detect without experience.

Recently the response of the cupric-selective electrode to EDTA in ammoniacal solution was reported. ${ }^{3}$ This response suggested the possibility of using the electrode for end-point detection in the sulfate procedure. This objectively determined end point would substantially improve the method. Furthermore, the use of instrumental end-point detection rather than visual end-point detection is an attractive option, particularly for analytical work in facilities designed for radioactive containment.

\section{EXPERIMENTAL METHOD}

\section{Principle}

The sulfate method consists of the following steps:

- Precipitating sulfate as $\mathrm{BaSO}_{4}$

$$
\mathrm{SO}_{4}{ }^{2-}+\mathrm{Ba}^{2+} \rightarrow \mathrm{BaSO}_{4} \downarrow
$$


- Dissolving $\mathrm{BaSO}_{4}$ in excess ammoniacal EDTA

$$
\mathrm{BaSO}_{4} \downarrow+\mathrm{H}_{2} \mathrm{EDTA}^{2-} \stackrel{\mathrm{NH}_{4} \mathrm{OH}}{\longrightarrow} \mathrm{BaEDTA}^{2-}+2 \mathrm{H}^{+}+\mathrm{SO}_{4}{ }^{2-}
$$

- Titrating unreacted EDTA with $\mathrm{La}^{3+}$

$$
\mathrm{H}_{2} \mathrm{EDTA}^{2-}+\mathrm{La}^{3+} \rightarrow \mathrm{LaEDTA}^{-}+2 \mathrm{H}^{+}
$$

The end point of Reaction 3 is detected by the cupric-selective electrode, which responds to EDTA in ammoniacal solution. ${ }^{3}$

\section{Reagents}

Barium chloride, 0.5M (104 $\left.\mathrm{g} \mathrm{BaCl}_{2} / 1\right)$.

Ethylenediaminetetraacetic acid (EDTA), $0.1 \mathrm{M}(37.22 \mathrm{~g}$ of primary standard $\mathrm{Na}_{2} \mathrm{H}_{2} \mathrm{EDTA} \cdot 2 \mathrm{H}_{2} \mathrm{O} / 1$ ) .

Lanthanum nitrate, $0.1 \mathrm{M}\left[20.090 \mathrm{~g} \mathrm{La}\left(\mathrm{NO}_{3}\right)_{3} / 1\right]$ standardized against primary standard EDTA.

Ammonium hydroxide, 12M.

\section{Apparatus}

Expanded scale $\mathrm{pH}$ meter, operated in $\mathrm{mV}$ mode (an automatic differential titrator is preferable).

Cupric-selective electrode, Orion Mode1 942900 (Orion Research, Cambridge, Massachusetts).

Double junction reference electrode, Orion Model 900200.

Centrifuge tubes, 15 or $30 \mathrm{ml}$.

Centrifuge.

Microburet, such as Digipet (Manostat Corp., New York), $1 \mathrm{ml}$.

Miscellaneous micropipets.

\section{Procedure}

1. Pipet the sample that contains about 0.05 millimole of sulfate into a centrifuge tube. The solution must not contain particulates; filter if necessary. 
2. Dilute to $>5 \mathrm{ml}$ and adjust $\mathrm{pH}$ to 1 to 3 with HC1.

3. Add $2 \mathrm{ml}$ of $0.5 \mathrm{M} \mathrm{BaCl}_{2}$ and $\mathrm{mix}$.

4. Heat centrifuge tubes in near-boiling water for 20 to $30 \mathrm{~min}$ to allow the precipitate to flocculate and to settle to the bottom of the tube.

5. Centrifuge the solution in the tube.

6. Remove the supernate (by transfer pipet) and discard.

7. Wash the precipitate three times with deionized water in $3 \mathrm{ml}$ portions. Slurry the precipitate, centrifuge, and discard the supernate each time.

8. Add 3 drops of concentrated $\mathrm{NH}_{4} \mathrm{OH}$ and $1000 \mu \mathrm{I}$ (by micropipet) of standard EDTA to the precipitate in the centrifuge tube. Swirl the solution to $\mathrm{mix}$ and dissolve the major portion of the precipitate.

9. Quantitatively transfer the mixture to a 50-m1 beaker. Add about $0.5 \mathrm{ml}$ ammonium hydroxide. Stir the mixture until all solids are dissolved (20 $\mathrm{min})$.

10. Titrate with standardized $\mathrm{La}\left(\mathrm{NO}_{3}\right)_{3}$ solution added from a microburet. Add the reagent in $5 \mu 1$ increments in the vicinity of the end point (Fig. I).

11. Determine the $\mathrm{ml}$ of $\mathrm{La}^{3+}$ titrant that corresponds to the end point (i.e., the inflection point, determined by the second derivative or other method).

12. Calculate the sulfate concentration as follows:

$$
\mathrm{M} \mathrm{SO}_{4}{ }^{2-}=\frac{(\mathrm{m} 1 \text { EDTA })(\mathrm{M} \mathrm{EDTA})-\left(\mathrm{m} 1 \mathrm{La}^{3+}\right)\left(\mathrm{M} \mathrm{La}^{3+}\right)}{\mathrm{m} 1 \text { sample }}
$$

\section{TITRATION CURVES}

Typical curves for titrating ammoniacal EDTA with $\mathrm{La}^{3+}$ in the presence and absence of $\mathrm{Ba}^{2+}$ are shown in Fig. 1. In the presence of barium, the changes in potential at the end point are considerably smaller, but they are still adequate for accurately locating the end point. The inflection point of the curve and the color change of the arsenazo indicator were essentially concurrent. 


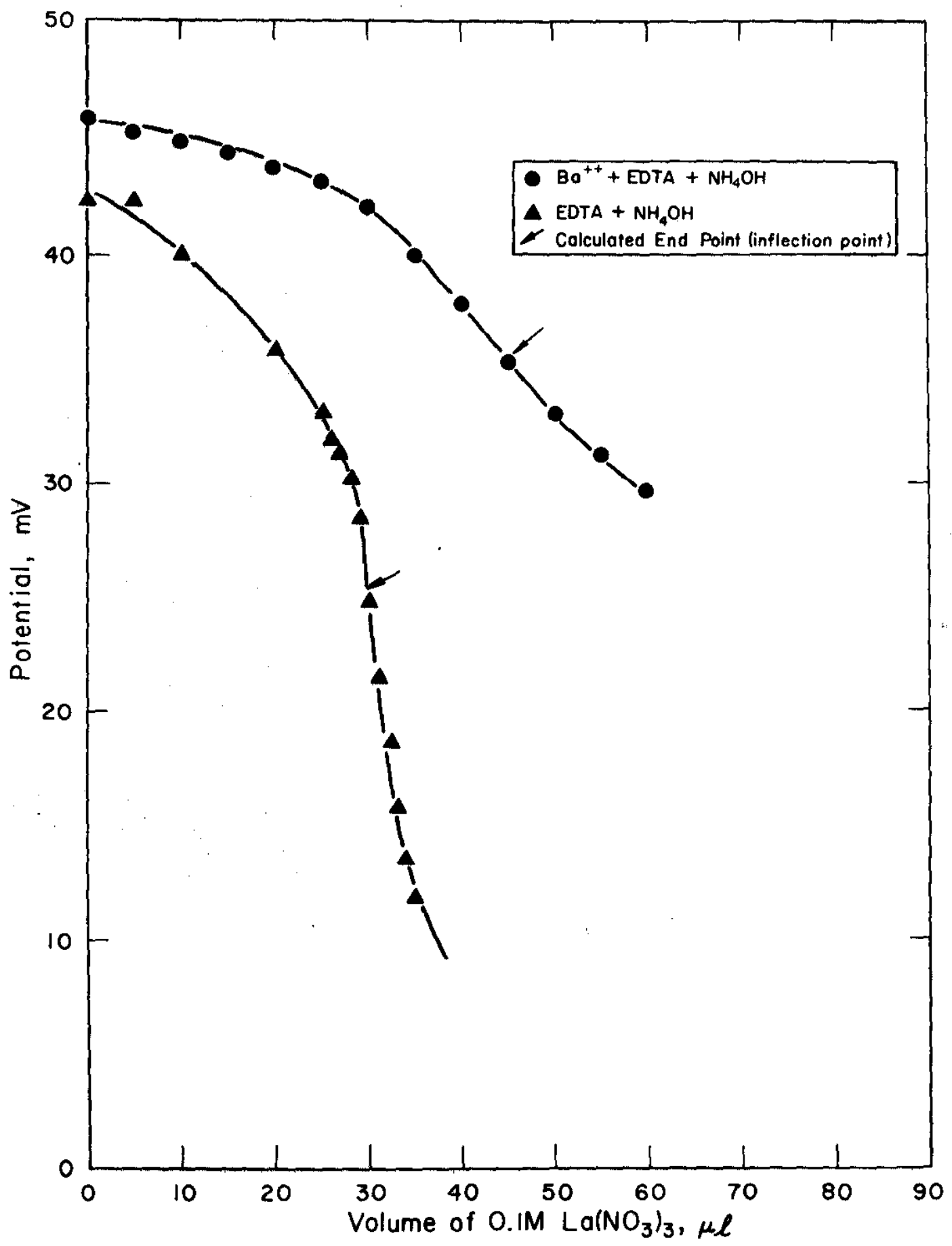

FIGURE 1. Potentiometric End Points Indicated by Cupric-Selective Electrode 


\section{EVALUATION OF METHOD}

The procedure was tested by analyzing solutions of $\mathrm{BaCl}_{2}$ and $\mathrm{H}_{2} \mathrm{SO}_{4}$ by the EDTA and classical titration methods. Chloride was determined by potentiometric titration with $\mathrm{AgNO}_{3}$ (silver electrode), and hydrogen ion was determined by titration with $\mathrm{NaOH}$ to $\mathrm{pH} 7$ (glass electrode). The results are shown in Table 1. The two methods agreed satisfactorily, even though the sulfate determined complexometrically may be biased high. This bias could reflect excess barium carried down with the $\mathrm{BaSO}_{4}$ precipitate.

TABLE 1

Comparison of EDTA Method with Classical Methods

$\begin{array}{llll}\text { Solution } & \text { Method } & \begin{array}{l}\text { Number of } \\ \text { Determinations }\end{array} & \begin{array}{l}\text { Conc. of Ion ( } \pm 95 \% \\ \text { Confidence Limit) }\end{array} \\ \mathrm{BaCl}_{2} & \mathrm{EDTA} & 6 & 0.1016 \pm 0.0010 \mathrm{M} \mathrm{Ba}^{2+} \\ & \mathrm{AgNO}_{3} \text { titration } & 4 & 0.1018 \pm 0.0027 \mathrm{M} \mathrm{Ba}^{2+} \\ \mathrm{H}_{2} \mathrm{SO}_{4} & \text { EDTA } & 4 & 0.03606 \pm 0.00019 \mathrm{M} \mathrm{SO}_{4}{ }^{2-} \\ & \mathrm{NaOH} \text { titration } & 4 & 0.03567 \pm 0.00036 \mathrm{M} \mathrm{SO}_{4}{ }^{2-}\end{array}$

\section{APPLICATION}

The method was used to determine sulfate in $3 \mathrm{M} \mathrm{HCl}$ solutions of simulated sludge prepared for the Savannah River Laboratory radioactive waste management program. ${ }^{4}$ The principal constituents of the sludge were iron, manganese, aluminum, uranium, and sodium, in various proportions. The results demonstrated the applicability of the method and also brought to light some limitations.

The recovery of sulfate that was added to a solution of sludge $(\mathrm{Fe}>\mathrm{U}>\mathrm{Mn}>\mathrm{Na}>\mathrm{Al}$ ), which contained little or no initial sulfate, was investigated. Table 2 shows that a considerable excess of $\mathrm{BaCl}_{2}$ was required to recover the added sulfate from this medium. Results were biased about $4 \%$ high, probably because some of the sludge constituents that react with EDTA were occluded with the barium sulfate precipitate. With another sludge solution $(\mathrm{Al}>>\mathrm{Mn}>\mathrm{Fe}>\mathrm{Na}>\mathrm{U})$, the relative standard deviation of four determinations was $3.5 \%$.

Sulfate concentrations of a series of dissolved sludge samples were determined by the EDTA method with arsenazo indicator and electrode end points. These samples were also analyzed by the nephelometric method with 2 -aminoperimidine. ${ }^{5}$ The results, most of which are single determinations, are shown in Table 3 . 
The three methods agree satisfactorily, particularly when the differences in sample volume are noted.

TABLE 2

Recovery of Sulfate Added to Solutions of Sludge (10-ml Sample Volume)

\begin{tabular}{llll} 
& \multicolumn{2}{c}{$\mathrm{SO}_{4}{ }^{2-}$ Conc., $M$} & \\
\cline { 2 - 3 } Amount of Precipitant & Added & Found & Bias, \% \\
$1 \mathrm{ml} 0.1 \mathrm{M} \mathrm{BaCl}_{2}$ & 0.0361 & 0.0328 & -9.4 \\
& & 0.0327 & \\
& & & \\
$2 \mathrm{~m} 10.5 \mathrm{M} \mathrm{BaCl}_{2}$ & 0.0361 & 0.0372 & +3.5 \\
& & 0.0376 &
\end{tabular}

TABLE 3

Comparison of Sulfate Concentration Determined Three Ways

\begin{tabular}{|c|c|c|c|c|c|c|}
\hline \multirow[b]{2}{*}{ Sample } & \multicolumn{2}{|c|}{ Complexometric Method } & \multicolumn{2}{|c|}{ Indicator } & \multicolumn{2}{|c|}{$\begin{array}{l}\text { 2-Aminoperimidine } \\
\text { NepheZometry }\end{array}$} \\
\hline & $\begin{array}{l}\text { Voliome, } \\
\mathrm{ml}\end{array}$ & $\mathrm{SO}_{4}{ }^{2-}, \mathrm{M}$ & $\begin{array}{l}\text { Votume, } \\
m z\end{array}$ & $\mathrm{SO}_{4}{ }^{2-}, \mathrm{M}$ & $\begin{array}{l}\text { Volume, } \\
\text { Vl }\end{array}$ & $\mathrm{SO}_{4}{ }^{2-}, \mathrm{M}$ \\
\hline 1 & 5 & $2.10 \times 10^{-4}$ & 10 & $<10^{-4}$ & 0.100 & $1.8 \times 10^{-4}$ \\
\hline 2 & 5 & $8.08 \times 10^{-4}$ & 20 & $6.3 \times 10^{-4}$ & 0.100 & $5.8 \times 10^{-4}$ \\
\hline 3 & 5 & $1.29 \times 10^{-3}$ & 10 & $1.38 \times 10^{-3}$ & 0.100 & $2.0 \times 10^{-3}$ \\
\hline 4 & 5 & $1.48 \times 10^{-3}$ & 20 & $1.45 \times 10^{-3}$ & 0.100 & $1.6 \times 10^{-3}$ \\
\hline 5 & 5 & $2.70 \times 10^{-3}$ & 20 & $2.80 \times 10^{-3}$ & 0.100 & $2.6 \times 10^{-3}$ \\
\hline 6 & 5 & $3.84 \times 10^{-3}$ & 20 & $3.26 \times 10^{-3}$ & 0.050 & $3.8 \times 10^{-3}$ \\
\hline 7 & 5 & $4.12 \times 10^{-3}$ & 10 & $3.96 \times 10^{-3}$ & 0.050 & $4.2 \times 10^{-3}$ \\
\hline 8 & 5 & $5.03 \times 10^{-3}$ & 20 & $4.87 \times 10^{-3}$ & 0.050 & $5.2 \times 10^{-3}$ \\
\hline
\end{tabular}




\section{CONCLUSIONS}

The method for indirectly determining sulfate by complexometric titration is improved when potentiometric end-point detection is used instead of visual end-point detection. The end points are unequivocal and objective. In addition, the use of the instrumental end point facilitates remote titrations with radioactive containment.

The method retains the limitations imposed by the nature of the barium sulfate precipitate. The finite solubility of barium sulfate in various media (such as $\mathrm{HCl}$ of the dissolved sludge solutions) requires a substantial excess of barium chloride to recover the sulfate quantitatively. Occlusion of barium or other ions from the solution will cause a positive bias. Barium contamination can be avoided by adding a nonionic surfactant, as suggested by Dimitt and Graham; ${ }^{6}$ this addition was not tried in the present work.

The method also involves back-titration, another limitation. The sample should consume about half of the EDTA added to achieve maximum accuracy. Because the volume is limited to $<20 \mathrm{ml}$ to reduce $\mathrm{BaSO}_{4}$ solubility and to enable convenient centrifugation, the best results will be achieved with samples that contain $>10^{-3} \mathrm{M} \mathrm{SO}_{4}{ }^{2-}$. 


\section{REFERENCES}

1. G. Schwarzenbach and H. Flaschka. CompZexometric Titrations. Second Eng1ish Edition, p 315, Methuen \& Co. Ltd., London (1969).

2. I. M. Kolthoff, E. B. Sande11, E. J. Meehan, and S. Bruckenstein. "Determination of Sulfur as Barium Sulfate." Chapter 27 in Quantitative Chemical Analysis, Fourth Edition. The MacMillan Company, Collier-Macmillan Limited, London (1969).

3. V. K. 01son, J. D. Carr, R. D. Hargens, and R. K. Force. "Potentiometric Response of Silver(I) Sulfide/Copper(II) Sulfide to Chelons and Applications for End-Point Detection in Chelometric Titrations." Anal. Chem. 48(8), 1228 (1976).

4. J. A. Stone. Evaluation of Concrete as a Matrix for Solidification of Savannah River Plant Waste. USERDA Report DP-1448, E. I. du Pont de Nemours and Company, Savannah River Laboratory, Aiken, SC (to be issued).

5. E. W. Baumann. Nephelometric Determination of Microgram Quantities of Sulfate with 2-Aminoperimidine. USERDA Report DP-1437, Savannah River Laboratory, E. I. du Pont de Nemours and Company, Aiken, SC (1976).

6. R. L. Dimitt and E. R. Graham. "Determination of Sulfate in Microgram Quantities as Barium-133 Sulfate Precipitate." Anal. Chem. 48(3), 604 (1976). 